www.jmscr.igmpublication.org

Impact Factor 5.84

Index Copernicus Value: 71.58

ISSN (e)-2347-176x ISSN (p) 2455-0450

crossref DOI: _https://dx.doi.org/10.18535/jmscr/v5i9.107

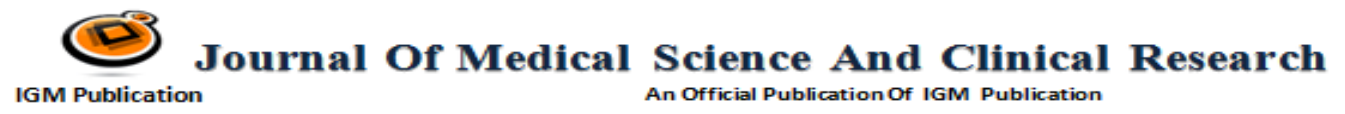

\title{
A Prospective Study on the Evaluation of Thyroid Function Status in Patients with Chronic Kidney Disease
}

\author{
Authors \\ Vivek Paul Benjamin $V^{1}$, Kirubakaran $S^{2^{*}}$, Elavarasan $K^{3}$, Natarajan $S^{4}$ \\ ${ }^{1,3}$ Post Graduate Student, Department of General Medicine, Meenakshi Medical College Hospital and \\ Research Institute, Chennai \\ ${ }^{2}$ Department of Community Medicine, Aarupadai Veedu Medical College \& Hospital, Pondicherry \\ ${ }^{4}$ Professor and HOD, Department of General Medicine, Meenakshi Medical College Hospital and Research \\ Institute, Chennai \\ Corresponding Author \\ Dr Kirubakaran S
}

Assistant Professor, Aarupadai Veedu Medical College, Pondicherry

Phone: 9791797372, Email: kirubasam01@gmail.com

\begin{abstract}
Background: Chronic Kidney Disease is a worldwide health problem with an increasing incidence and prevalence. Abnormalities in the structure and function of the thyroid gland and in the metabolism and plasma concentration of thyroid hormones are common in patients with Chronic Kidney Disease. In view of variability of thyroid function tests in patients with CKD in previous studies, a prospective study of various thyroid functions is undertaken to establish a correlation if any between thyroid dysfunction and severity of renal diseases.
\end{abstract}

Method: Total number of 100 patients with Chronic Kidney Disease on conservative management who were admitted in MMCHRI was selected in this prospective study.

Results: Out of the 100 patients with CKD 48 patients had low T3 syndrome $(0.2-1.9 n \mathrm{~g} / \mathrm{ml}$, mean 0.605) which accounts for $48 \%$ of the patients, 22 patients had low T4 syndrome $(0.5-9.5 \mu \mathrm{g} / \mathrm{ml}$, mean 5.631) which accounts for $22 \%$ of the patients and 10 patients had primary hypothyroidism TSH >20 $\mu \mathrm{IU} / \mathrm{ml}$. Excluding Primary Hypothyroidism, analysis of serum T3,T4 and TSH in the study subjects shows very high significance, $p<0.001$. Distribution of Thyroid. Dysfunction in this study among various creatinine clearance levels showed that as glomerular filtration rate declines, number of patients with low T3 syndrome increased, $p<0.05$, significant difference. In patients with low T3 syndrome, the mean values of TSH in various stages of renal disease are within normal range mean 4.85, values of TSH did not show any linear correlation with GFR. Number of patients with low T4 syndrome did not correlate with severity of renal disease.

Conclusion: Thyroid Dysfunction occurred in 58\% of the patients with chronic kidney disease in our study, it does not indicate a state of hypothyroidism, but a reflection of the state of chronic illness/malnutrition. The low T3 state of CKD can be

viewed as being protective, promoting conservation of protein. The number of patient with low T3 syndrome progressively increase with the severity of renal failure.

Keywords: Chronic Kidney Disease, glomerular filtration rate, End stage renal disease, Thyroid dysfunction 


\section{INTRODUCTION}

Chronic kidney disease (CKD) is a public health problem throughout the world with an increasing rate of the prevalence and incidence, high cost and poor outcomes. ${ }^{1}$ In the total of world population, $5-7 \%$ of the population is affected by chronic kidney disease affects and is more common in developing countries. ${ }^{2,3}$ This CKD leads to excretory, metabolic and synthetic failure terminating into the accumulation of non-protein nitrogenous substances and produces various clinical manifestations. ${ }^{4,5}$

End stage renal disease (ESRD) is illustrated as a terminal stage of chronic kidney disease that without replacement therapy would result in death. One such system in the body is thyroid hormonal system. Kidney is very closely related to thyroid. This because of the fact that it is the only other organ that competes with iodide clearance. ${ }^{6}$ In a country such as China and India, where the number of elderly people is increasing, it is estimated that number of cases of kidney failure will also increase disproportionately. ${ }^{7}$

Kidneys participate in the metabolism and elimination of thyroid hormones. ${ }^{8}$ The function of thyroid is affected in many ways due to CKD. Thus, in CKD, thyroid hormone metabolism is impaired. ${ }^{5,9}$

According to the most recent NHANES (National Health and Nutrition Examination Survey) between 1999 and 2006, there are 26 million (13\%) out of approximately 200 million United states residents aged 20 years and older are reported to suffer from CKD stages 1-4. Among all other age groups it is reported that the elderly people are a growing segment of the population and at increased risk for renal disease. The observations of this survey have also been authenticated throughout the developed world countries such as Asia, Europe, and Australia as well as in developing regions such as India, China and Africa. 10,11

Patients with CKD have many signs and symptoms suggestive of thyroid dysfunction like sallow complexion, edema, dry skin, cold intolerance, decreased BMR, asthenia and hyporeflexia is reported in patient with CKD. So even the slightest change in the prognosis in the CKD levels, it is difficult to exclude thyroid dysfunction on mere clinical background.

Many studies have been carried out on thyroid function in CKD patients. The results of these studies were seemed to be inconsistent. Hypothyroidism, Hyperthyroidism and euthyroidism all have been reported. The relationship linking thyroid dysfunction and severity of CKD is not clear till date.

In view of variability of thyroid function test in patients with CKD in previous studies, a prospective clinical and biochemical study on thyroid function in CKD patients in the Department of General Medicine, from a Meenakshi Medical College Hospital and Research Institute, Chennai has been undertaken. This study was carried out to study the prevalence of thyroid dysfunction in patients with chronic kidney disease, correlate thyroid dysfunction and severity of renal diseases and to differentiate primary thyroid diseases from thyroid dysfunction due to chronic kidney disease.

\section{MATERIALS AND METHODS}

A prospective study is conducted on 100 patients of, who are diagnosed to have chronic kidney disease and being admitted in Meenakshi Medical College Hospital and Research Institute, Chennai, during the period of September 2015 to September 2017. These samples are selected by using simple random sampling method. Statistical parameters mean, standard deviation (SD) and correlations are used and parametric and non-parametric tests are used for the analysis. Informed consent was obtained from all the patients.

\section{Inclusion criteria}

i. Patients with chronic kidney disease with the following signs and symptoms:

Symptoms of uraemia for 3 months or more, Elevated blood urea, serum creatinine and decreased creatinine clearance, Ultra sound 
evidence of chronic kidney disease, Bilateral contracted kidneys - size $<8 \mathrm{~cm}$ in male and size $<7 \mathrm{~cm}$ in female and Poor cortico-medullary differentiation, Type 2 or 3 renal parenchymal changes, Supportive laboratory evidence of CKD like anemia, low specific gravity, changes in serum electrolytes, etc. and Radiological evidence of renalosteodystrophy

ii. Patients who fulfill the criteria for CKD and who are on conservative management.

\section{Exclusion criteria}

1. Patients on peritoneal dialysis or hemodialysis

2. Nephrogenic range of proteinuria

3. Low serum protein especially albumin

a) Other conditions like - Acute illness, recent surgery, trauma or burns, Diabetes mellitus, Liver diseases, Drugs altering thyroid profile like amiodarone, steroids, dopamine, phenytoin, betablocker, estrogen pills, and iodine-containing drugs.

Detailed clinical history and clinical examination is undertaken with preference to thyroid and renal diseases. The following investigations were performed. They are 1. Urine routine and microscopic examination, 2. Peripheral smear for anemia and burr cells, 3. Renal parameters like blood urea, serum Creatinine and Creatinine clearance (using Cockcroft — Gault formula), 4. Serum electrolytes including calcium and phosphorous, 5. Serum cholesterol 6. 24 hours urine protein and serum protein, 7. ECG, chest $\mathrm{X}$ and $2 \mathrm{D}$ echo, 8. $\mathrm{X}$ ray wrist, forearm and spine for evidence of renalosteodystrophy, 9.USG abdomen for evidence of chronic kidney disease, 10. FNAC in patients presenting with thyroid swelling.

After selecting the patients, fulfilling the above criteria, about $5 \mathrm{ml}$ of blood sample is collected in non-heparinised serum bottle and sent for thyroid profile. Quantitative determination of $\mathrm{T}_{3}, \mathrm{~T}_{4}, \mathrm{TSH}$ is done by Enzyme Linked Immunosorbent Assay.

\section{RESULTS}

One hundred patients with signs and symptoms of Chronic Kidney Disease (CKD) were included in the study. Mean age of patients with Chronic Kidney Disease $(\mathrm{CKD})$ is $45.08 \pm 13.78 . \mathrm{t}=22.47$ and the $\mathrm{p}$ value is $=>0.05$. There is significant difference in age among males and females; $70 \%$ were male and $30 \%$ were female. The age varied from 12-70 years; 22 patients were $\leq 30$ years of age, 62 patients were in 30-60 years and 16 patients were $\geq 60$ years of age.

The T3 levels varied from $0.2-1.9 \mathrm{ng} / \mathrm{ml}$ (table 1), the mean value being 0.589 . Excluding the patients with primary hypothyroidism, the mean value was 0.605 , this value was in low normal limit.

Table-1: Serum concentration of thyroid hormone

\begin{tabular}{|c|c|c|c|c|c|}
\hline 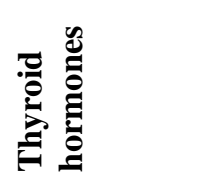 & 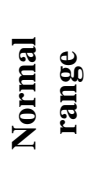 & $\stackrel{\Xi}{\mathbb{E}}$ & $\dot{\theta}$ & 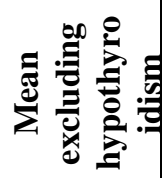 & 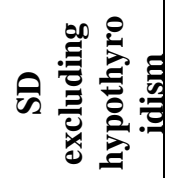 \\
\hline $\begin{array}{ll}\text { Serum } & \text { T3 } \\
\mathrm{ng} / \mathrm{ml}\end{array}$ & $\begin{array}{c}0.6- \\
2.1\end{array}$ & 0.589 & 0.315 & 0.605 & 0.399 \\
\hline $\begin{array}{l}\text { Serum } \\
\mu \mathrm{g} / \mathrm{dl} 4\end{array}$ & $5-13$ & 4.31 & 2.145 & 5.98 & 2.01 \\
\hline $\begin{array}{ll}\text { Serum } & \text { TSH } \\
\mu \mathrm{IU} / \mathrm{ml} & \end{array}$ & $0.4-7$ & 6.31 & 5.74 & 3.98 & 3.24 \\
\hline
\end{tabular}

Ultrasound abdomen showed evidence of CKD in all patients, contracted kidney was present in $90 \%$ of the patients and remaining patients had poor corticomedullary differentiation. Among the 100 patients in our study 54 of them had low serum T3 levels (54\%), 14 patients among the low serum T3 level also had high TSH value of $>20 \mu \mathrm{IU} / \mathrm{ml}$ with low T4 levels and also symptoms suggestive of hypothyroidism. Therefore these 14 patients were grouped under "Primary Hypothyroidism" as per the criteria (14\%). Twenty four patients had low T4 levels accounting for $24 \%$ of the patients (Table 2).

Table-2: Distribution of low T3 and T4 among various levels of TSH

\begin{tabular}{|l|c|c|c|c|}
\hline \multirow{2}{*}{$\begin{array}{l}\text { TSH level } \\
\boldsymbol{\mu I U} / \mathrm{ml}\end{array}$} & \multicolumn{2}{|c|}{$\begin{array}{c}\text { No. of Patients with } \\
\text { Low T3 }\end{array}$} & \multicolumn{2}{c|}{$\begin{array}{c}\text { No. of Patients } \\
\text { with Low T4 }\end{array}$} \\
\cline { 2 - 5 } & No & \% & No & \% \\
\hline$<7$ & 38 & 55.88 & 16 & 66.67 \\
\hline $7.1-20$ & 16 & 23.53 & 2 & 8.33 \\
\hline$>20$ & 14 & 20.59 & 6 & 25 \\
\hline total & $\mathbf{6 8}$ & $\mathbf{1 0 0}$ & $\mathbf{2 4}$ & $\mathbf{1 0 0}$ \\
\hline
\end{tabular}


Mean value of serum T4 among 100 patients was 5.631, excluding hypothyroidism patients the mean value was $5.98 \mu \mathrm{g} / \mathrm{ml}$. this value is within low normal level of T4. Excluding 12 hypothyroid patients who have low T4 values, 24 other patients counting to $44 \%$ had T4 level below normal and low T3 syndrome (Table 4).

Of the 100 patients, 52 patients had GFR of $<10 \mathrm{ml} / \mathrm{min}$ accounting to $52 \%, 80$ patients had GFR ranging from 11-20 $\mathrm{ml} / \mathrm{min}$ accounting for another $38 \%$ and the remaining 20 patients had GFR $>20 \mathrm{ml} / \mathrm{min}$ accounting for $20 \%$. Blood urea varied from $64-177 \mathrm{mg} / \mathrm{dl}$ and creatinine levels varied from $3 \mathrm{mg}-17.2 \mathrm{mg} / \mathrm{dl}, 24$ hours urine protein excretion was $<1 \mathrm{~g} /$ day in all the patients in our study (figure 1). Chi square test $=25.74$ $\mathrm{p}<0.05$ Significant.

Figure 1: Analysis of serum T3, T4 and TSH excluding hypothyroidism

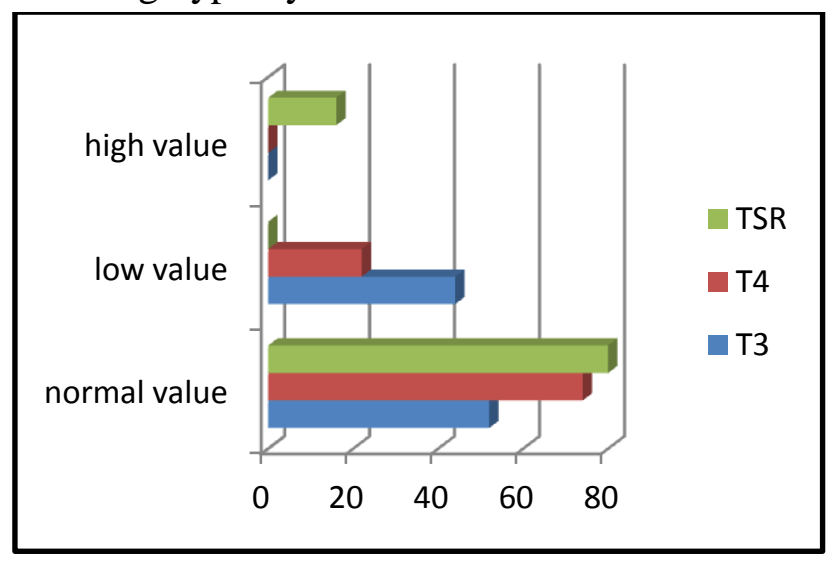

Serum calcium and phosphorous were normal in all our patients, $80 \%$ of the patients had anaemia with peripheral smear revealing normocytic normochromic anaemia in $72 \%$ and hypochromic anaemia in $8 \%$ of the patients. Burr cells were present in $40 \%$ of the cases, one patient had pleural effusion in our study, two patients in the study showed evidence of osteodystrophy and none of the patients had pericardial effusion.

Age incidence of low T3 syndrome was done in this study as shown in table 6 , it showed that $27.27 \%$ of the CKD patients who had low T3 level were 30 years of age or below and $48.39 \%$ of the patients were between the ages 31-60 years, as the age increases the number of patients with low T3 also increased, $50 \%$ of the patients with low T3 were above the age of 60 years. Chi square test $=2.07 \mathrm{p}<0.05$ NS. Sex incidence of low T3 syndrome in one study showed that $54.29 \%$ of males had low T3 and 20\% of the females have low T4 syndrome. Chi square test $=1.04 \mathrm{p}<0.05$ NS

Among the 100 patients in our study 44 of them had low serum T3 levels (84\%), 12 patients among the low serum T3 level also had high TSH value of $>20 \mu \mathrm{IU} / \mathrm{ml}$ with low T4levels and also symptoms suggestive of hypothyroidism. Therefore these 12 patients were grouped under "Primary Hypothyroidism" as per the criteria (10\%). 30 patients had low T4 levels accounting for $30 \%$ of the patients. Chi square test $=1.58$ $\mathrm{p}<0.05 \mathrm{NS}$

Symptoms of hypothyroidism such as tiredness, somnolence, weight gain, cold intolerance, hoarseness of voice etc were also studied in the sample population. $84 \%$ (84 patients) had the symptoms as shown in table 8.38 patients of the 44 who had low T3 syndrome had symptoms accounting for $86.36 \%$ and 12 patients among who were hypothyroid had symptoms accounting for $100 \% .52$ patients with CKD did not show thyroid dysfunction, among these 52 patients 34 of them had symptoms of hypothyroidism which accounts to $65.38 \%$. According to our study, number of patients with low T3 increased with increase in the severity of renal failure in spite of low T3. The serum T4levels varied from $0.5-$ $9.5 \mu \mathrm{g} / \mathrm{dl}$.

Number of patients with low T4 does not correlate with severity of renal disease (Table 3 ).

Table-3: Distribution of low T3 and T4 syndrome in this study

\begin{tabular}{|l|c|c|c|c|c|}
\hline \multirow{2}{*}{$\begin{array}{l}\text { Creatinine } \\
\text { Clearance } \\
\text { ml/mm }\end{array}$} & \multirow{2}{*}{$\begin{array}{c}\text { No. of } \\
\text { patients }\end{array}$} & \multicolumn{2}{|c|}{$\begin{array}{c}\text { Low T3 } \\
\text { Syndrome }\end{array}$} & \multicolumn{2}{c|}{$\begin{array}{c}\text { Low T4 } \\
\text { Syndrome }\end{array}$} \\
\cline { 3 - 6 } & & no & $\%$ & no & $\%$ \\
\hline$<15 \mathrm{ml} / \mathrm{min}$ & 5 & 2 & 40 & 1 & 20 \\
\hline $15-29 \mathrm{ml} / \mathrm{min}$ & 48 & 32 & 66.667 & 6 & 12.5 \\
\hline $30-44 \mathrm{ml} / \mathrm{min}$ & 34 & 10 & 29.41 & 8 & 23.52 \\
\hline $45-59 \mathrm{ml} / \mathrm{min}$ & 13 & 2 & 15.38 & 1 & 7.69 \\
\hline Total & 100 & 46 & 44 & 16 & 16 \\
\hline
\end{tabular}


Among the 100 patients, TSH was normal in 76 patients $(76 \%)$ and values between $7.1-20 \mu \mathrm{IU} / \mathrm{ml}$ in 10 patients $(29 \%)$. It was elevated $>20 \mu \mathrm{IU} / \mathrm{ml}$ in 10 patients $(100 \%)$ of which 6 were female and 4 were male. According to our study, in patients with low T3 syndrome, the mean values of TSH in various stages of renal disease are within normal range, values of TSH did not show any linear correlation with GFR (table 4).

Table-4: Distribution of thyroid dysfunction among various Creatinine clearance

\begin{tabular}{|l|c|c|c|c|c|}
\hline \multirow{2}{*}{$\begin{array}{l}\text { Creatinine } \\
\text { Clearance } \\
\text { ml/mm }\end{array}$} & \multirow{2}{*}{$\begin{array}{c}\text { No. of } \\
\text { patients }\end{array}$} & \multicolumn{2}{|c|}{$\begin{array}{c}\text { Low T3 } \\
\text { Syndrome }\end{array}$} & \multicolumn{2}{c|}{ Hypothyroidism } \\
\cline { 3 - 6 } & & No & $\%$ & no & $\%$ \\
\hline$<15 \mathrm{ml} / \mathrm{min}$ & 5 & 2 & 40 & 0 & 0 \\
\hline $\begin{array}{l}15-29 \\
\mathrm{ml} / \mathrm{min}\end{array}$ & 48 & 32 & 66.667 & 9 & 18.75 \\
\hline $\begin{array}{l}30-44 \\
\mathrm{ml} / \mathrm{min}\end{array}$ & 34 & 10 & 29.41 & 6 & 17.64 \\
\hline $\begin{array}{l}45-59 \\
\mathrm{ml} / \mathrm{min}\end{array}$ & 13 & 2 & 15.38 & 1 & 7.69 \\
\hline Total & 100 & 46 & 46 & 16 & 16 \\
\hline
\end{tabular}

Excluding hypothyroidism T3 levels were studied in relation to GFR, mean value of serum T3 was low $(0.749 \mathrm{ng} / \mathrm{ml})$ only in patients with GFR $<10 \mathrm{ml} / \mathrm{min}$ (table 15 ). The mean value was low normal in patients with GFR $>10 \mathrm{ml} / \mathrm{min}$.

Table-5: Correlation of thyroid hormones with severity of renal failure excluding hypothyroidism

\begin{tabular}{|c|c|c|c|c|c|c|}
\hline \multirow{2}{*}{$\begin{array}{l}\text { Creatinine } \\
\text { Clearance } \\
\mathrm{ml} / \mathrm{mm}\end{array}$} & \multicolumn{2}{|c|}{ T3 (ng/dl) } & \multicolumn{2}{|c|}{ T4 ( $\mu \mathrm{g} / \mathrm{dl})$} & \multicolumn{2}{|c|}{$\begin{array}{c}\text { TSH } \\
(\mu \mathrm{IU} / \mathrm{ml})\end{array}$} \\
\hline & $\sum^{\mathscr{E}}=$ & 兵 & $\sum_{\Sigma}^{\mathbb{E}}=$ & क्ष & $\stackrel{\mathbb{E}}{\Sigma}=$ & 会 \\
\hline$<15 \mathrm{ml} / \mathrm{min}(\mathrm{n}=5)$ & 0.74 & 0.39 & 8.19 & 3.98 & 8.06 & 2.95 \\
\hline $\begin{array}{l}15-29 \mathrm{ml} / \mathrm{min} \\
(\mathrm{n}=48)\end{array}$ & 0.75 & 0.32 & 5.14 & 2.84 & 4.59 & 4.19 \\
\hline $\begin{array}{l}30-44 \mathrm{ml} / \mathrm{min} \\
(\mathrm{n}=34)\end{array}$ & 0.63 & 0.29 & 6.18 & 3.12 & 4.18 & 3.87 \\
\hline $\begin{array}{l}45-59 \mathrm{ml} / \mathrm{min} \\
(\mathrm{n}=13)\end{array}$ & 0.84 & 0.39 & 7.18 & 3.75 & 6.78 & 3.75 \\
\hline
\end{tabular}

Data analysis was done with the help of computer using Epidemiological Information Package EPI 2016.Using this software, frequencies, percentage, mean, standard deviation, chi square and " $\mathrm{p}^{\text {ee }}$ values were calculated. A " $\mathrm{p}$ " value less than 0.05 is taken to denote significant relationship.

\section{DISCUSSION}

The prevalence of Chronic kidney disease (CKD) and end-stage renal disease (ESRD) have become worldwide public health problem. Chronic renal failure (CRF) is characterized by a persistently abnormal glomerular filtration rate. According to a study carried out in an Indian population, they verified that the crude and age-adjusted ESRD incidence rates at 151 and 232 per million populations, respectively. ${ }^{11}$

The functioning of the thyroid gland is very crucial action inside the human body as it normalizes majority of the body's physiological actions metabolism, development, protein synthesis, and influencing other hormone functions. The function of the thyroid gland is to take iodine, found in many foods, and convert it into thyroid hormones: thyroxine (T4) and triiodothyronine (T3). These hormones can also have significant impact on kidney disease so it is important to consider the physiological association of thyroid dysfunction in relation to CKD. $^{12}$

Mean age of patients with Chronic Kidney Disease $(\mathrm{CKD})$ is $45.08 \pm 13.78 . \mathrm{t}=22.47$ and the $\mathrm{p}$ value is $=>0.05$. There is significant difference in age among males and females. The mean age of males in our study group was $48.24+9.18$ years. The mean age of females in our study group is $47.8+9.13$ years. ${ }^{13}$

Among 100 patients with Chronic Kidney Disease (CKD) fulfilling the criteria for CKD who were on conservative management were studied, 70 were male and 30 were female, their age varied from 12-70 years. Our study group is similar as compared to the study by Avasthi G et al, ${ }^{14}$ which was $73 \%$ males and $26 \%$ females.

Among the 100 patients in our study 54 of them had low serum T3 levels (54\%), 14 patients among the low serum T3 level also had high TSH value of $>20 \mu \mathrm{IU} / \mathrm{ml}$ with low T4 levels and also symptoms suggestive of hypothyroidism. Therefore these 14 patients were grouped under "Primary Hypothyroidism" as per the criteria (14\%). Twenty four patients had low T4 levels 
accounting for $24 \%$ of the patients. These results correlate ewith the other studies conducted by Pakhle et al. ${ }^{11}$

Analyzing the mean value of serum T4 among 100 patients was 5.631, excluding hypothyroidism patients the mean value was $5.98 \mu \mathrm{g} / \mathrm{ml}$. this value is within low normal level of T4. Excluding 12 hypothyroid patients who have low T4 values, 24 other patients counting to $44 \%$ had T4 level below normal and low T3 syndrome (Table 4). Our results correlate with the Senthilnathan et al., ${ }^{13}$ study where not all the patients with CKD have low T3 and T4. Only 35\% (35 patients) of patients had altered Thyroid Profile. Remaining 65\% of patients had normal thyroid profile. Among 35\% of these patients, $15 \%$ have only low T3 level with normal T4 level. Remaining 4\% have both low T3 and T4 level. The percentage of patients having low T3 and T4, gradually increase with increase in stage.

In our study the blood urea varied from $64-177$ $\mathrm{mg} / \mathrm{dl}$ and creatinine levels varied from $3 \mathrm{mg}-$ $17.2 \mathrm{mg} / \mathrm{dl}, 24$ hours urine protein excretion was $<1 \mathrm{~g} /$ day in all the patients. Our results correlated with the other studies conducted by Pakhle et al., ${ }^{11}$ were the mean serum creatinine and blood urea levels in the patients were reported to be $6.17 \pm 0.78 \mathrm{mg} / \mathrm{dl}$ and $94.92 \pm 14.36 \mathrm{mg} / \mathrm{dl}$ respectively; and Shamsuddin et al 2014, 15 reported mean serum creatinine levels of $5.83 \pm 0.69 \mathrm{mg} / \mathrm{dl}$ and that of blood urea was reported to be $96.23 \pm 12.24 \mathrm{mg} / \mathrm{dl}$. The results were more or less similar to present study suggesting severe kidney dysfunction.

Serum calcium and phosphorous were normal in all our patients, $80 \%$ of the patients had anaemia with peripheral smear revealing normocytic normochromic anaemia in $72 \%$ and hypochromic anaemia in $8 \%$ of the patients.

Our study showed that $27.27 \%$ of CKD patients who had low T3 level were 30 years of age or below and $48.39 \%$ of the patients were between the ages $31-60$ years, as the age increases the number of patients with low T3 also increased, $50 \%$ of the patients with low T3 were above the age of 60 years. Many studies conducted in CKD patients showed low $\mathrm{T}_{3}$ values. Low $\mathrm{T}_{3}$ had been reported in Ramirez et al ${ }^{16}$, Hegedu P Iglesias and JJ Diez ${ }^{17}$ and many others.

Among the 100 patients in our study 44 of them had low serum T3 levels (84\%), 12 patients among the low serum T3 level also had high TSH value of $>20 \mu \mathrm{IU} / \mathrm{ml}$ with low T4levels and also symptoms suggestive of hypothyroidism. Out study results are in consistent with the results of Ramirez et a1 ${ }^{61}$ study showing low T3, low T4 and normal or mild elevation of TSH. Therefore these 12 patients were grouped under "Primary Hypothyroidism" as per the criteria (10\%). 30 patients had low T4 levels accounting for $30 \%$ of the patients.

The patients with hypothyroidism witnessed symptoms like such as tiredness, somnolence, weight gain, cold intolerance, hoarseness of voice etc were also studied in the sample population. $84 \%$ (84 patients) had the symptoms as shown in table 8. 38 patients of the 44 who had low T3 syndrome had symptoms accounting for $86.36 \%$ and 12 patients among who were hypothyroid had symptoms accounting for $100 \%$. 52 patients with CKD did not show thyroid dysfunction, among them $34(65.38 \%)$ had symptoms of hypothyroidism. Patients with low T3 increased with increase in the severity of renal failure (Table 8 ) in spite of low T3 are seen in our study. The serum T4levels varied from $0.5-9.5 \mu \mathrm{g} / \mathrm{dl}$.

Among the 100 patients, TSH was normal in 76 patients $(76 \%)$ and values between $7.1-20 \mu \mathrm{IU} / \mathrm{ml}$ in 10 patients $(29 \%)$. It was elevated $>20 \mu \mathrm{IU} / \mathrm{ml}$ in 10patients $(100 \%)$ of which 6 were female and 4 were male. According to our study, in patients with low T3 syndrome, the mean values of TSH in various stages of renal disease are within normal range, values of TSH did not show any linear correlation with GFR. These results correlate with the studies by Pakhle et al., ${ }^{11}$ where there was a positive significant correlation was found between the levels of serum creatinine with levels of $\mathrm{T} 3$ and TSH. 


\section{CONCLUSION}

To conclude, in patients with CKD Thyroid dysfunction occurs in $58 \%$ of the patients, the alteration in the values of $T_{3}$ and $T_{4}$ in CKD can be viewed as protective, promoting conservation of protein. Incidence of hypothyroidism is increased in patients with chronic kidney disease. The number of patients with low $\mathrm{T}_{3}$ and $\mathrm{T}_{4}$ syndrome progressively increase with the severity of chronic kidney disease. Excluding patients with hypothyroidism $\mathrm{T}_{3}$ level is low in $46 \%$ of the patients, $\mathrm{T}_{4}$ level is low in $20 \%$ of the patients. Serum level of $\mathrm{T}_{3}$ and $\mathrm{T}_{4}$ has no correlation with the severity of chronic kidney disease.

\section{LIMITATIONS OF THIS STUDY}

Thyroid dysfunction was studied in patients with CKD irrespective of the etiology of CKD therefore individual correlation of the etiology of CKD with thyroid dysfunction could not be studied. Thyroid dysfunction was not studied in patients on dialysis, as dialysis itself affects the thyroid profile independently of CKD.

\section{REFERENCES}

1. Andrew S. Levey, Josef Coresh, Ethan Balk, Annamaria T. Kausz, Ronald D. Perrone. National Kidney Foundation Practice Guidelines for Chronic Kidney Disease: Evaluation, Classification, and Stratification. MD Ann Intern Med.2003;139:137147.

2. Christopher PJ, Selvaraj S, Brinda, et al. A population-based study on chronic kidney disease in Kanyakumari Government Medical College. J. Evid. Based Med. Healthc. 2016; 3(97), 5358-5360

3. Ajay Kumar Katiyar, S. K. Katiyar. "Study of Lipid Profile and Homocysteine Levels in Cases of Chronic Kidney Disease". Journal of Evolution of Medical and Dental Sciences 2014; Vol. 3, Issue 26, June 30; Page: 7135-7142.

4. Kaptein EM, Quion-Verde H, Chooljian CJ, Tang WW, Friedman PE, Rodriquez HJ et al. The thyroid in end stage renal disease, Medicine (Baltimore) 1988; 67:187- 97.

5. Lakshmi Keerthana, Anil Kumar. Study of Thyroid and Lipid Profile in Chronic Kidney Disease. International Journal of Medical and Health Research, 2016,2; 3; Page No. 06-09

6. Kaptein E et al. The Thyroid in end stage renal diseases, Medicine, 1988; 67:187-97.

7. Jha V, Garcia-Garcia G, Iseki K. Chronic kidney disease: global dimension and perspectives. Lancet Jul 20 2013; 382(9888):260-272.

8. Gattineni J, Sas D, Dagan, Baum MG, Effect of thyroid hormone on the postnatal renal expression of NHE8, American Journal of Physiology, Renal Physiology, 2008; 294:198-204.

9. Malyszko J, Malyszko J, Wolczynski S, Mysliwiec M. Adiponectin, leptin and thyroid hormones in patients with chronic renal failure and on renal replacement therapy: are they related? Nephrol Dial Transplant. 2006; 21(1): 145-52.

10. Bakris GL., Ritz E., Hypertension and kidney disease. A marriage that should be prevented. Kidney Int 2009; 75: 449-452.

11. Pakhle K, Parikh R, Jain A, Kashyap P, Dave D, Bhate A. Thyroid dysfunctions in patients with chronic renal failure. Int J Res Med Sci 2017;5:2773-8.

12. Mohamedali M, Maddika SR, Vyas A, Iyer V, Cheriyath P. Thyroid disorders and chronic kidney disease. Int J Nephrol. 2014;2014:1-6.

13. Gopalan Senthilnathan, Raman Prabhakaran. A Study of Evaluation of Thyroid Function Status In Patients With Chronic Kidney Disease. IOSR Journal of Dental and Medical Sciences, 2017; 16(6) ver. IX, 103-106.

14. Avasthi G, Malhotra S, Narang APS, Sengupta S. Study of thyroid function on patients of chronic renal failure. Indian $\mathbf{J}$ Nephrol. 2001;11:165-9. 
15. Shamsuddin M, Baig MSA, Hemalatha, Kumari S. Thyroid dysfunctions in patients with chronic renal failure. Int J Biol Med Res. 2014; 5(1): 3911-3914.

16. Ramirez $\mathrm{G}$ et al. Thyroid abnormalities in renal failure. A study of 53 patients on chronic dialysis. Ann Internal Medicine, 1973; 79, 500-4.

17. Gattineni J, Sas D, Dagan, Baum MG, Effect of thyroid hormone on the postnatal renal expression of NHE8, American Journal of Physiology, Renal Physiology, 2008; 294:198-204. 